\title{
Grass pollen seasons in Poland against a background of the meteorological conditions
}

\author{
Dorota Myszkowska1*, Katarzyna Piotrowicz², Monika Ziemianin', Kazimiera Chłopek3, Katarzyna \\ Dąbrowska-Zapart ${ }^{3}$, Idalia Kasprzyk ${ }^{4}$, Łukasz Grewling ${ }^{5}$, Barbara Majkowska-Wojciechowska ${ }^{6}$, Małgorzata \\ Malkiewicz ${ }^{7}$, Małgorzata Nowak ${ }^{5}$, Krystyna Piotrowska-Weryszko ${ }^{8}$, Małgorzata Puc ${ }^{9,10}$, Elzbieta Weryszko- \\ Chmielewska ${ }^{11}$
}

${ }^{1}$ Department of Clinical and Environmental Allergology, Jagiellonian University Medical College, Śniadeckich 10, 31-531 Cracow, Poland

${ }^{2}$ Institute of Geography and Spatial Management, Jagiellonian University, Gronostajowa 7, 30-387 Cracow, Poland

${ }^{3}$ Faculty of Earth Sciences, University of Silesia, Będzińska 60, 41-200 Sosnowiec, Poland

${ }^{4}$ Department of Environmental Biology, University of Rzeszów, Zelwerowicza 4, 35-601 Rzeszów, Poland

${ }^{5}$ Laboratory of Aeropalynology, Faculty of Biology, Adam Mickiewicz University, Umultowska 89, 61-614 Poznań, Poland

${ }^{6}$ Department of Immunology, Rheumatology and Allergy, Medical University of Lodz, Pomorska 251, 92-213 Łódź, Poland

${ }^{7}$ Laboratory of Paleobotany, Department of Stratigraphical Geology, University of Wrocław, Cybulskiego 34, 50-205 Wrocław, Poland

${ }^{8}$ Department of General Ecology, University of Life Sciences in Lublin, Leszczyńskiego 58, 20-950 Lublin, Poland

${ }^{9}$ Department of Botany and Nature Conservation, Faculty of Biology, University of Szczecin, Felczaka 3c, 71-412 Szczecin, Poland

${ }^{10}$ Molecular Biology and Biotechnology Center, Faculty of Biology, University of Szczecin, Wąska 13, 71-415 Szczecin, Poland

${ }^{11}$ Department of Botany, University of Life Sciences in Lublin, Akademicka 15, 20-950 Lublin, Poland

\section{Abstract}

The paper refers to the estimation of Poaceae pollen seasons in Poland in selected areas. The aim of the study was to present the long-term variability of the start, end and duration of grass pollen seasons and the seasonal pollen index (SPI) in Poland against a background of the meteorological conditions over pollen seasons. The study was performed in eight Polish cities in 1992-2014 (the common seasons were 2003-2012). Pollen season start was relatively stable in the studied period, the seasons began about the 10th of May, a bit earlier in the south part of Poland. Pollen season ends were more changeable in comparison to the season start and fluctuated from the middle of July to the middle of September. SPI clearly depended on temperature and precipitation in April-August. Daily maximum pollen concentrations were achieved between the end of May and the first decade of July and no evident relationship between this day and weather conditions was found, apart from 2004.

Keywords: grass pollen; pollen seasons; seasonal variability; weather conditions

\section{Introduction}

Weather changes during a year influence the natural environment, including the pollen season dynamics of different taxa, especially the start of the season and the pollen season intensity. Particular attention is paid to grass pollen seasons, because Poaceae are the main components of meadow vegetation, grassland and steppe and are the source of the strongest pollen allergens in West and Central Europe [1]. In Poland about 300 species of Poaceae occur, belonging to the most frequent genera: Festuca (36 species), Bromus (26 species) and Poa (20 species) [2-3]. Because the great

\footnotetext{
* Corresponding author. Email: dorota.myszkowska@uj.edu.pl
}

Handling Editor: Agnieszka Grinn-Gofroń number of grass species flower in different time periods, grass pollen is observed in the air during the whole vegetation season. Grasses release pollen from May to October, and according to Szczepanek (1994) their pollen seasons are determined as "long seasons" [4].

Poaceae pollen allergens are the main cause of the allergic rhinitis (AR) provoked by plant pollen. In Poland, up to $90 \%$ of patients with AR are sensitive to grass pollen [5]. The allergenic clinical symptoms depend on the allergens occurrence in the air, and the symptoms intensity correlate with the concentration of allergenic particles [6,7].

In the majority of regions in Poland the grass pollen concentration increases in late May and early June, achieving the highest concentrations in mid-July, while the last pollen grains are observed at the end of September and at the beginning of October [8]. In temperate climate zone, 
characteristic for Poland, plants show a wind-pollination cycle associated with the seasons of the year, but climate changes have modified the start and duration of the seasons in recent years. Gehrig [9] reported, that the exceptionally warm summer in 2003 in Basel (Switzerland) influenced the grass pollen season timing strongly. Air temperature in June-August was 5-times higher than the long-term mean value and rainfall during June-October achieved only about $60 \%$ of the common sum. The indicated meteorological conditions had an evident impact on the earlier grass pollen occurrence (1-2 weeks earlier than mean value in the multi-year period), while the end of the season occurred 7-33 days earlier than mean value.

Piotrowicz and Myszkowska [10] indicated cloudiness, sunshine, precipitation and wind direction as factors significantly influencing the grass pollen concentration over the pollen season. In the sunny days, the anthers start to dehisce and pollen is released. Piotrowska [11] reported the statistically significant relationship between the grass pollen season start and temperature (min., max., mean) and also the number of days with minimum temperature above $5.6^{\circ} \mathrm{C}$. The impact of weather conditions on the pollen season dynamics is considered in the regional and wider scale. A multi-center studies on Poaceae pollen seasons in a country scale were performed in the Netherlands [12], Spain [13] and Great Britain [14]. Sanchez-Mesa et al. [15] published the comparative results obtained in Spain and Great Britain. It must be also mentioned about the comparative study on the grass pollen season dynamics in 12 European aerobiological centres of a great geoclimatic diversity $[16,17]$. Smith et al. [18] indicated the influence of NAO (North Atlantic Oscillation) on Poaceae pollen seasons in Europe.

The aim of the study was to present the long-term variability of the start, end and duration of grass pollen seasons and the seasonal pollen index (SPI) in eight Polish cities against a background of the meteorological conditions over pollen seasons.

\section{Material and methods}

\section{Aeropalynological data}

The studies were performed in eight cities in Poland in 1996-2014 (Tab. 1). The volumetric method was employed in pollen monitoring using a Hirst type trap (Lanzoni s.r.l., Burkard Ltd.). The traps work continuously taking samples of airborne particles with a flow rate of $101 \mathrm{~min}^{-1}$. The particles were placed on the Melinex adhesive tape wrapped around the moving drum. Pollen grains were stained with Basic Fuchsine or Safranin, with no impact on the counting quality. Every week Melinex tape was changed and cut into seven segments corresponding to $24 \mathrm{~h}$ periods. Microscopic slides were prepared according to the instruction by Stach and Kasprzyk [19]. For pollen grain identification the atlas of Moore et al. [20] as reference book was used. Twelve vertical lines or four horizontal lines on each slide were analyzed. Results were expressed as the number of pollen grains (PG) per cubic meter of the air over 24 hours $\left(\mathrm{PG} / \mathrm{m}^{3}\right)$. In the majority of cities the traps were installed at heights recommended by the EAS (European Aerobiology Society, Quality Control Working Group; 15-25 m above ground level) [21].

Pollen seasons were calculated using the $95 \%$ method, where the start of the season was defined as the date when $2.5 \%$ of the seasonal pollen total was trapped and the end of the season as the date, when $97.5 \%$ of the seasonal pollen total was reached [22]. The basic statistics, like arithmetic mean, minimum, maximum, standard deviation, coefficient of variation were applied in the descriptive statistics of the season characteristics (season start, season end, season duration, SPI value, maximum concentration and the day, when it was achieved). The SPI value is described as a seasonal total concentration in the determined season. Due to the fact that the different data series were used, the mean values of the season start, end and duration were calculated for the common period 2003-2012 to compare these season characteristic in all studied stations.

Tab. 1 Study sites information.

\begin{tabular}{|c|c|c|c|c|c|}
\hline $\begin{array}{l}\text { Study site } \\
\text { (city) }\end{array}$ & Coordinates & $\begin{array}{l}\text { Altitude (m } \\
\text { a.s.l.) }\end{array}$ & Climate; country area & $\begin{array}{l}\text { Studied grass } \\
\text { pollen seasons }\end{array}$ & $\begin{array}{l}\text { Height of } \\
\text { sampler location } \\
\text { (m a.g.l.) }\end{array}$ \\
\hline Szczecin & $\begin{array}{l}53^{\circ} 26^{\prime} \mathrm{N} \\
14^{\circ} 33^{\prime} \mathrm{E}\end{array}$ & 52 & $\begin{array}{l}\text { Temperate, the influence of maritime polar } \\
\text { air from the Atlantic Ocean, frequent clouds; } \\
\text { north, northwestern }\end{array}$ & $2000-2014$ & 21 \\
\hline Wrocław & $\begin{array}{l}51^{\circ} 06^{\prime} \mathrm{N} \\
17^{\circ} 01^{\prime} \mathrm{E}\end{array}$ & $105-155$ & $\begin{array}{l}\text { Temperate and moderate, the encounter of } \\
\text { oceanic and continental influences; west, } \\
\text { southwestern }\end{array}$ & 2003-2014 & 20 \\
\hline Poznań & $\begin{array}{l}52^{\circ} 24^{\prime} \mathrm{N} \\
16^{\circ} 53^{\prime} \mathrm{E}\end{array}$ & $65-92$ & $\begin{array}{l}\text { Temperate, transitional between Atlantic Ocean } \\
\text { and continental influences; west, central }\end{array}$ & $1996-2014$ & 33 \\
\hline Sosnowiec & $\begin{array}{l}50^{\circ} 17^{\prime} \mathrm{N} \\
19^{\circ} 08^{\prime} \mathrm{E}\end{array}$ & 263 & $\begin{array}{l}\text { Temperate and moderate, the encounter of } \\
\text { oceanic and continental influences; south }\end{array}$ & $1997-2014$ & 20 \\
\hline Łódź & $\begin{array}{l}51^{\circ} 47^{\prime} \mathrm{N} \\
19^{\circ} 28^{\prime} \mathrm{E}\end{array}$ & 150 & Temperate and moderate; central & $2003-2014$ & 15 \\
\hline Kraków & $\begin{array}{l}50^{\circ} 04^{\prime} \mathrm{N} \\
19^{\circ} 59^{\prime} \mathrm{E}\end{array}$ & 220 & $\begin{array}{l}\text { Temperate, changeable weather, greenhouse } \\
\text { effect; south }\end{array}$ & $1992-2014$ & 20 \\
\hline Rzeszów & $\begin{array}{l}50^{\circ} 01^{\prime} \mathrm{N} \\
22^{\circ} 02^{\prime} \mathrm{E}\end{array}$ & $200-215$ & Temperate and moderate; south, southeastern & $1997-2012$ & 12 \\
\hline Lublin & $\begin{array}{l}51^{\circ} 14^{\prime} \mathrm{N} \\
22^{\circ} 32^{\prime} \mathrm{E}\end{array}$ & 197 & $\begin{array}{l}\text { Impact of continental masses of air; south, } \\
\text { southeastern }\end{array}$ & $2001-2014$ & 18 \\
\hline
\end{tabular}




\section{Meteorological data}

Characteristics of meteorological conditions were performed using mean daily and monthly temperature, precipitation in the studied cities, obtained in the local meteorological stations. In case of Sosnowiec, the meteorological data came from meteorological station in Katowice. The other sources used to complete data were: Monthly Climate Monitoring Bulletin developed by the Institute of Meteorology and Water Management - National Research Institute (IMGW-PIB; http://www.imgw.pl).

The Spearman rank correlation test was used to find the relation between the pollen season characteristics and the meteorological elements (Statistica, Version 10).

\section{Results}

\section{Pollen seasons start}

In Poland, grass pollen seasons started usually in May. In the southern part of the country (Wrocław, Sosnowiec, Kraków, Rzeszów) grass pollen seasons began about the middle of May, while in the stations located in central and northwestern regions the pollen seasons started between 20 th to 24th of May (Fig. 1). However, the latest pollen season start was detected in Lublin, where the season start was relatively stable (according to the $S D$ value 5.71 days) (Tab. 2). In comparison, the most variable grass pollen season start was found in Kraków, probably because of the longest data series (23 years; Tab. 2).

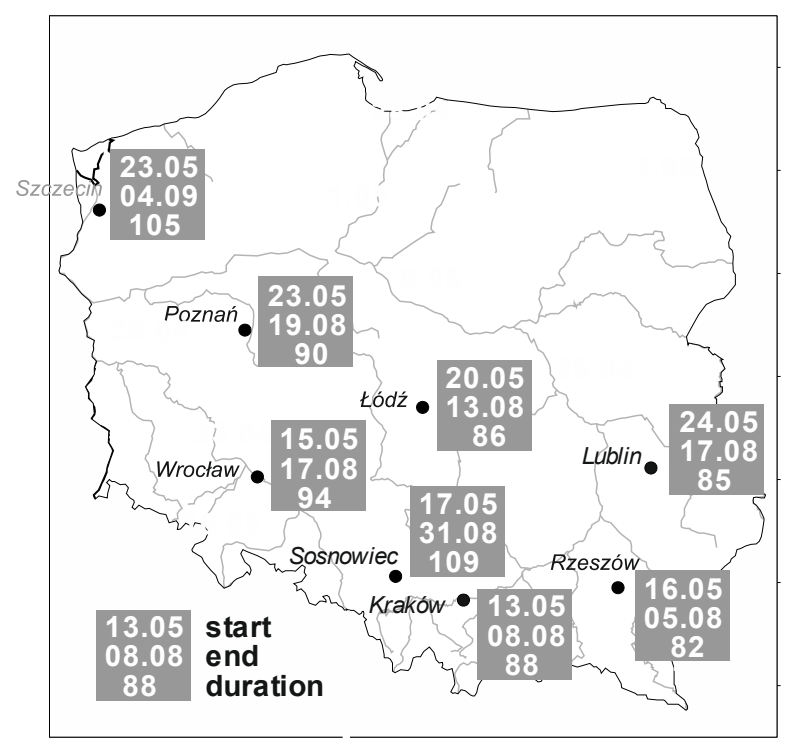

Fig. 1 Mean grass pollen season start and end dates and season duration in the selected station in 2003-2012.

Analysis of the impact of weather conditions on the grass pollen season start showed that this season characteristic coincidence with the course of monthly average air temperature in April and May (Tab. 3). This phenomenon was the most evident in 2010, when grass pollen seasons started in the south-eastern Poland within the long-term average (mid-May), but in Wrocław, Poznań and Szczecin the grass pollen seasons were one of the latest (Tab. 2, Fig. 2). In these regions (western Poland) mean monthly temperature in May 2010 was relatively low. According to the classification of IMGW-PIB May 2010 was described as "cool" (Fig. 3). Isolines of average air temperature anomalies coincided with the dates of the grass pollen season starts in all analyzed stations.

\section{Pollen season ends}

Pollen season ends in the studied time were more variable then season starts, both in the temporal and spatial scale. The seasons have finished the earliest in Rzeszów, the latest in Szczecin (Fig. 1, Tab. 2). In the southwestern part of Poland, the grass pollen season end vary in time the most evidently (Wrocław), in opposite to the northwestern Poland (Szczecin; $V \%=7.13$ vs. $V \%=2.87$; Tab. 2 ).

\section{Pollen season duration}

Grass pollen seasons lasted the shortest in the eastern part of Poland (82-85 days on average), and have been longer in the south and central part of the country (86-94 days), the longest seasons were observed in the northwestern regions and in Sosnowiec (105-109 days; Fig. 1).

The duration of pollen seasons was associated with the data series (Tab. 2). However, analysis of the extreme values of the seasons length leads to the conclusion that extremely short seasons (less than 70 days) occurred mainly in the south, especially in the south-western part of the country. The longest pollen season was determined in Szczecin (Tab. 2).

\section{Seasonal pollen index (SPI)}

The analyses of the seasonal pollen index indicated that the least intensive pollen seasons occurred in Kraków and Wrocław (2500 PG/m $\mathrm{m}^{3}$ on average; Tab. 2, Fig. 4), which could have resulted from the low SPI values in Kraków in the 90s of the 20th century. The highest pollen load was found in Lublin and Szczecin in all studied seasons (Tab. 2, Fig. 4).

Analyses of monthly temperature during the season indicated the significant correlation between SPI value in June and temperature in this month (Tab. 3). The most evident relationship was found in Łódź $(r=0.713 ; P<0.05)$ and Rzeszów ( $r=0.689 ; P<0.05)$, while the weakest, not statistically significant relationship was obtained in Poznan $(r=0.13 ; P>0.05)$. In case of Szczecin, temperature in July proved to be the best correlated with SPI value $(r=0.553 ; P$ $<0.05$ ), however, the highest negative correlation was found between the SPI and temperature in July-August value in Łódź $(r=-0.519)$. Considering the sum of precipitation in May-August and June-August, the positive correlation between precipitation and SPI value was found in the most stations (Kraków, Łódź, Poznań, Lublin, Sosnowiec; $r>0.40$; $P<0.05)$. In general, the highest pollen load occurred in all analyzed stations in warm and wet months, what was clearly seen in July 2010, which was classified as "extremely warm" with the higher than the average (Fig. 5).

\section{Maximum pollen concentrations}

Maximum pollen concentrations were achieved between 150 and 190 day of the year (between the end of May and the 
Tab. 2 Grass pollen season characteristics in the studied stations calculated using the 95\% method.

\begin{tabular}{|c|c|c|c|c|c|c|c|c|}
\hline $\begin{array}{l}\text { Monitoring } \\
\text { station }\end{array}$ & $\begin{array}{c}\text { Rzeszów } \\
\text { 1997-2012 }\end{array}$ & $\begin{array}{c}\text { Kraków } \\
\text { 1992-2014 }\end{array}$ & $\begin{array}{l}\text { Sosnowiec } \\
1997-2014\end{array}$ & $\begin{array}{c}\text { Wroclaw } \\
2003-2014\end{array}$ & $\begin{array}{l}\text { Lublin } 2001- \\
2014\end{array}$ & $\begin{array}{c}\text { Łódź 2003- } \\
2014\end{array}$ & $\begin{array}{c}\text { Poznań 1996- } \\
2014\end{array}$ & $\begin{array}{c}\text { Szczecin } \\
2000-2014\end{array}$ \\
\hline \multicolumn{9}{|c|}{ Pollen season start (date) } \\
\hline Mean & 17.05 & 17.05 & 17.05 & 15.05 & 24.05 & 20.05 & 23.05 & 22.05 \\
\hline Min. (year) & $\begin{array}{c}09.05(2000 \\
09,10)\end{array}$ & $02.05(2009)$ & $04.05(2000)$ & $27.04(2007)$ & $\begin{array}{c}15.05(2001 \\
02)\end{array}$ & 01.05 (2014) & $12.05(2002)$ & $03.05(2000)$ \\
\hline Max. (year) & $27.05(2005)$ & 04.06 (1996) & $03.06(2010)$ & $30.05(2010)$ & $01.06(2006)$ & 29.05 (2004) & $5.06(1997)$ & 07.06 (2010) \\
\hline$S D$ & 6.28 & 9.23 & 7.93 & 8.73 & 5.71 & 7.29 & 6.37 & 8.36 \\
\hline$V \%$ & 4.57 & 6.72 & 5.79 & 6.45 & 3.97 & 5.18 & 4.44 & 5.89 \\
\hline \multicolumn{9}{|c|}{ Pollen season end (date) } \\
\hline Mean & 06.08 & 11.08 & 02.09 & 17.08 & 17.08 & 13.08 & 16.08 & 04.09 \\
\hline Min. (year) & $16.07(2008)$ & $22.07(2003)$ & $12.08(2011)$ & $26.07(2010)$ & $04.08(2010)$ & $18.08(2014)$ & 25.07 (1999) & 22.08 (2007) \\
\hline Max. (year) & $20.08(2005)$ & 02.09 (1994) & 24.09 (1998) & $06.09(2006)$ & $30.08(2011)$ & 27.08 (2009) & $5.09(2006)$ & $15.09(2004)$ \\
\hline$S D$ & 8.22 & 12.12 & 11.30 & 16.33 & 7.56 & 12.34 & 12.47 & 7.10 \\
\hline$V \%$ & 3.77 & 5.43 & 4.61 & 7.13 & 3.30 & 5.48 & 5.47 & 2.87 \\
\hline \multicolumn{9}{|c|}{ Pollen season duration (days) } \\
\hline Mean & 82 & 87 & 110 & 94 & 85 & 86 & 86 & 106 \\
\hline Min. (year) & $61(2008)$ & $66(2012)$ & $76(2010)$ & $58(2010)$ & $67(2010)$ & $57(2004)$ & $65(1999)$ & $80(2010)$ \\
\hline Max. (year) & $98(2000)$ & $109(2004)$ & $134(1998)$ & $118(2011)$ & $100(2011)$ & $101(2009)$ & 105 (2012) & $132(2000)$ \\
\hline$S D$ & 9.77 & 12.91 & 12.62 & 17.62 & 9.34 & 12.40 & 14.19 & 11.70 \\
\hline$V \%$ & 11.95 & 14.86 & 21.42 & 18.68 & 10.95 & 14.48 & 16.59 & 10.99 \\
\hline \multicolumn{9}{|c|}{ SPI (seasonal pollen index; PG/m³) } \\
\hline Mean & 4896 & 2317 & 4256 & 2642 & 5965 & 3491 & 3995 & 5738 \\
\hline Min. (year) & $3693(2000)$ & 805 (1995) & $1770(1998)$ & $2120(2011)$ & $4106(2011)$ & $2329(2012)$ & $2328(2000)$ & $1983(2000)$ \\
\hline Max. (year) & $6056(2011)$ & $5666(1997)$ & $6474(2000)$ & $3184(2010)$ & $7939(2010)$ & 4555 (2005) & 7522 (1997) & 8389 (2014) \\
\hline$S D$ & 719.35 & 1101.41 & 1339.33 & 415.98 & 1156.38 & 606.37 & 1332.43 & 1562.21 \\
\hline$V \%$ & 14.69 & 47.52 & 31.46 & 15.74 & 19.39 & 17.37 & 33.35 & 27.22 \\
\hline
\end{tabular}

Tab. 3 The Spearman correlation coefficients between selected parameters and meteorological elements. Statistically significant relationships are given in bold $(P=0.05)$.

\begin{tabular}{|c|c|c|c|c|c|c|c|c|}
\hline Monitoring station & $\begin{array}{c}\text { Rzeszów } \\
\text { 1997-2012 }\end{array}$ & $\begin{array}{c}\text { Kraków } \\
\text { 1992-2014 }\end{array}$ & $\begin{array}{c}\text { Sosnowiec } \\
1997-2014\end{array}$ & $\begin{array}{c}\text { Wrocław } \\
\text { 2003-2014 }\end{array}$ & $\begin{array}{c}\text { Lublin } \\
2001-2014\end{array}$ & $\begin{array}{c}\text { Łódź } \\
\text { 2003-2014 }\end{array}$ & $\begin{array}{c}\text { Poznań } \\
\text { 1996-2014 }\end{array}$ & $\begin{array}{c}\text { Szczecin } \\
2000-2014\end{array}$ \\
\hline \multicolumn{9}{|l|}{ Pollen season start (date) } \\
\hline$T_{\text {mean }}$ in April & -0.349 & -0.545 & -0.618 & -0.518 & 0.019 & -0.063 & -0.587 & -0.328 \\
\hline$T_{\text {mean }}$ in May & -0.104 & -0.226 & -0.536 & -0.341 & -0.565 & -0.028 & -0.758 & -0.676 \\
\hline \multicolumn{9}{|c|}{ Pollen concentration in June $\left(\mathrm{PG} / \mathrm{m}^{3}\right)$} \\
\hline$T_{\text {mean }}$ in June & 0.689 & 0.336 & 0.336 & 0.397 & 0.436 & 0.713 & 0.130 & 0.260 \\
\hline Precipitation in June & -0.038 & 0.234 & -0.196 & -0.592 & -0.087 & 0.263 & -0.024 & -0.056 \\
\hline \multicolumn{9}{|c|}{ Pollen concentration in July $\left(\mathrm{PG} / \mathrm{m}^{3}\right)$} \\
\hline$T_{\text {mean }}$ in July & -0.009 & 0.022 & 0.337 & 0.500 & 0.334 & 0.538 & 0.501 & 0.553 \\
\hline Precipitation in July & 0.120 & 0.630 & -0.171 & 0.045 & -0.371 & 0.119 & 0.431 & -0.298 \\
\hline \multicolumn{9}{|c|}{ SPI (seasonal pollen index; PG/m³) } \\
\hline$T_{\text {mean }}$ in July-August & 0.317 & 0.159 & 0.157 & -0.186 & 0.123 & -0.519 & -0.263 & 0.448 \\
\hline Precipitation in June-August & 0.246 & 0.650 & 0.066 & -0.181 & -0.418 & -0.562 & 0.346 & 0.329 \\
\hline
\end{tabular}


Rzeszów
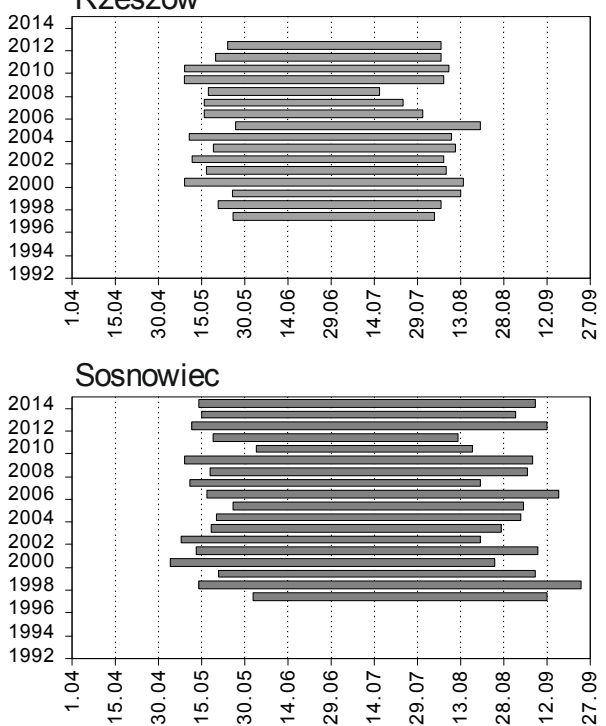

Lublin

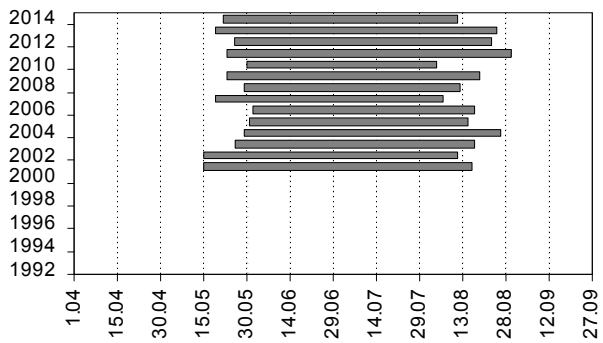

Poznań

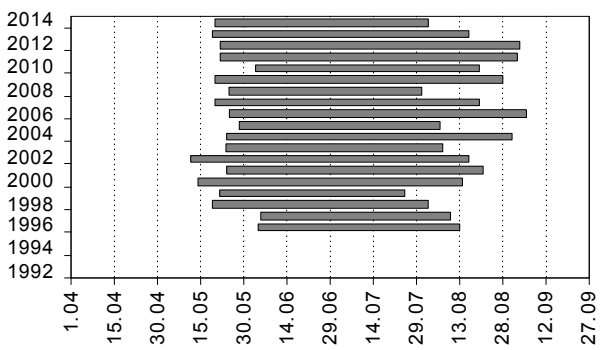

Kraków
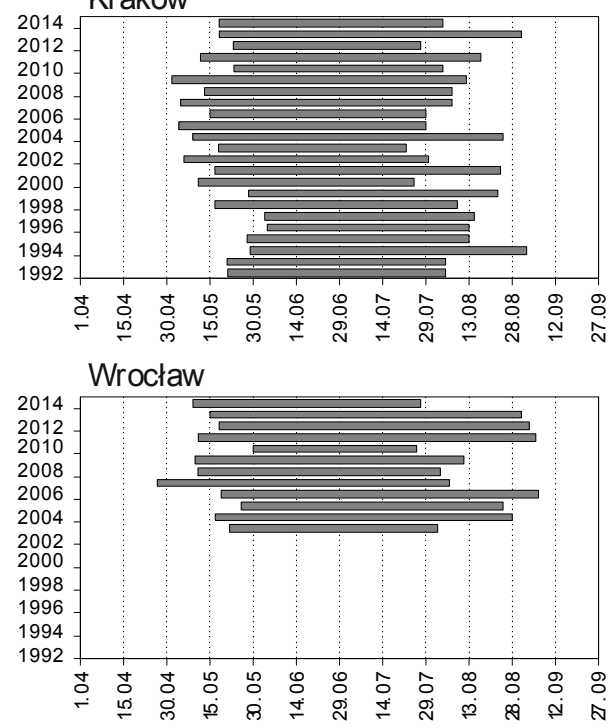

Łódź

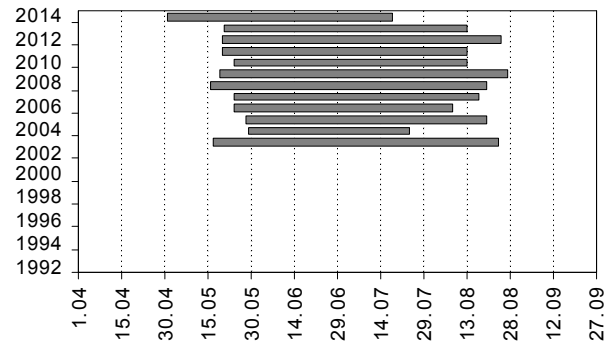

Szczecin

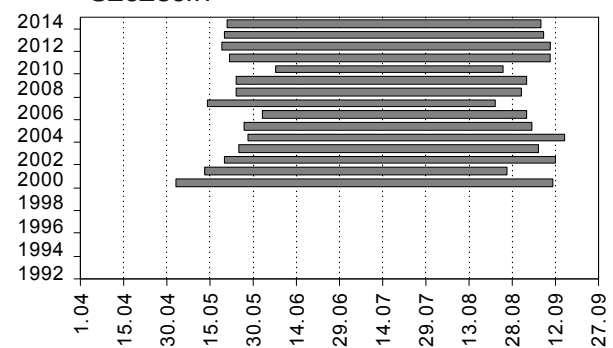

Fig. 2 The term of the grass pollen seasons in the selected stations in the studied years.
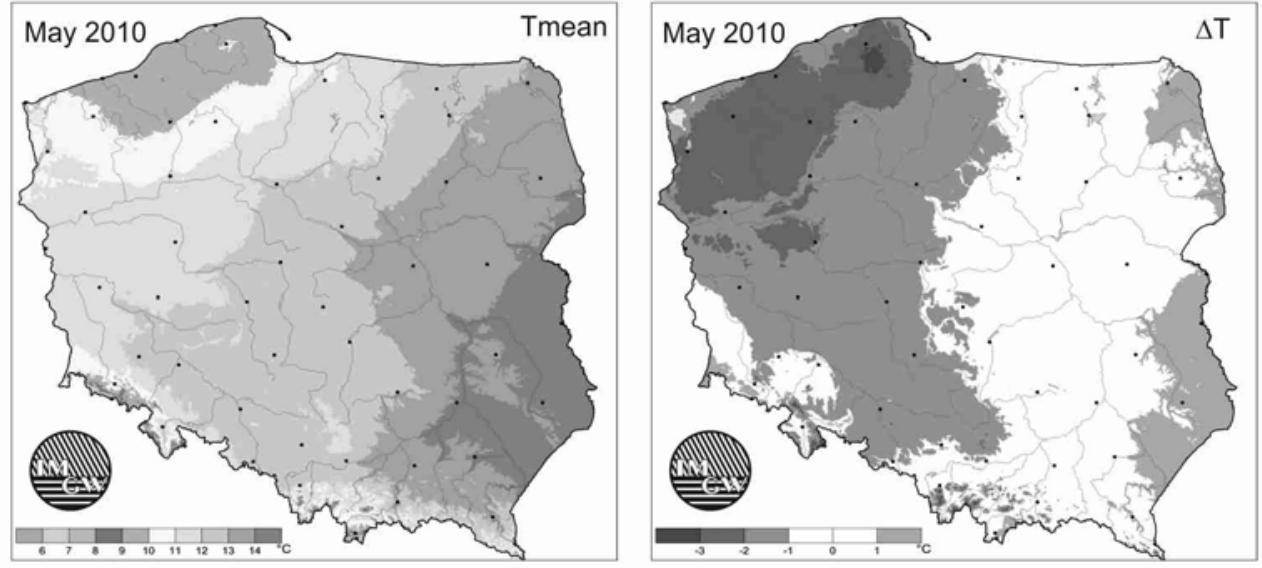

Fig. 3 Monthly mean air temperature $\left(T_{\text {mean }}\right)$ and anomalies of monthly mean air temperature $(\Delta T)$ in May 2010 in relationship to normal period 1971-2000 (Monthly Climate Monitoring Bulletin, May 2010, http://www.imgw.pl). 

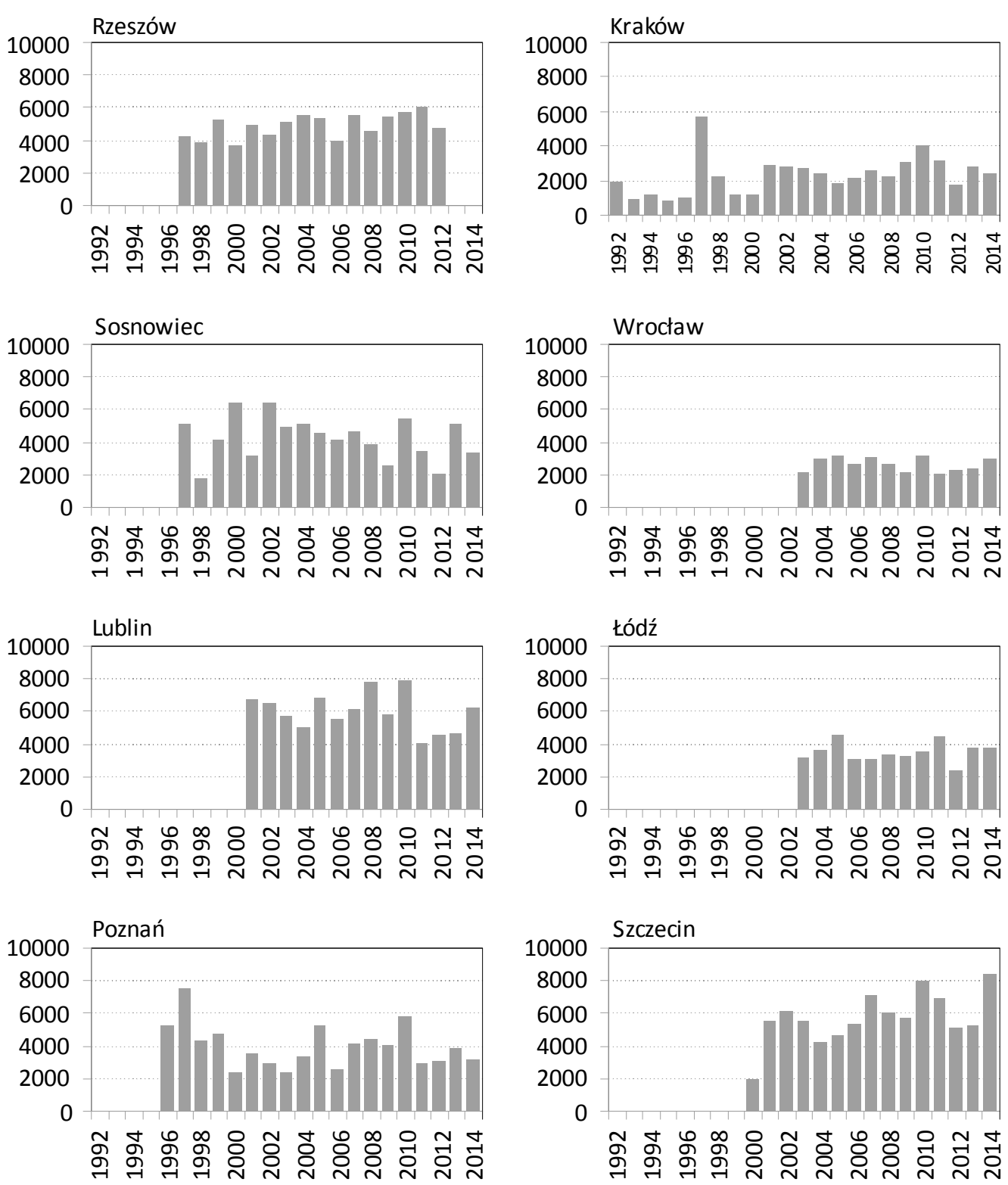

Fig. 4 Seasonal pollen index of grass $\left(\mathrm{PG} / \mathrm{m}^{3}\right)$ pollen in the selected stations in the studied years.
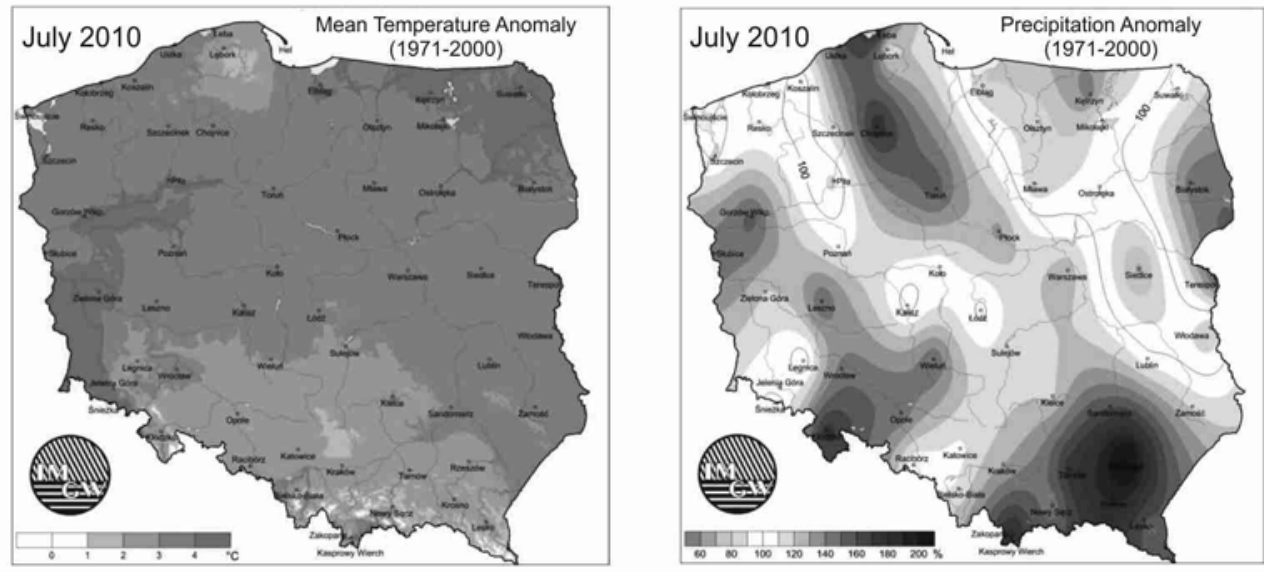

Fig. 5 Anomalies of monthly mean air temperature and precipitation in July 2010 in relationship to normal period 1971-2000 (Monthly Climate Monitoring Bulletin, July 2010, http://www.imgw.pl). 


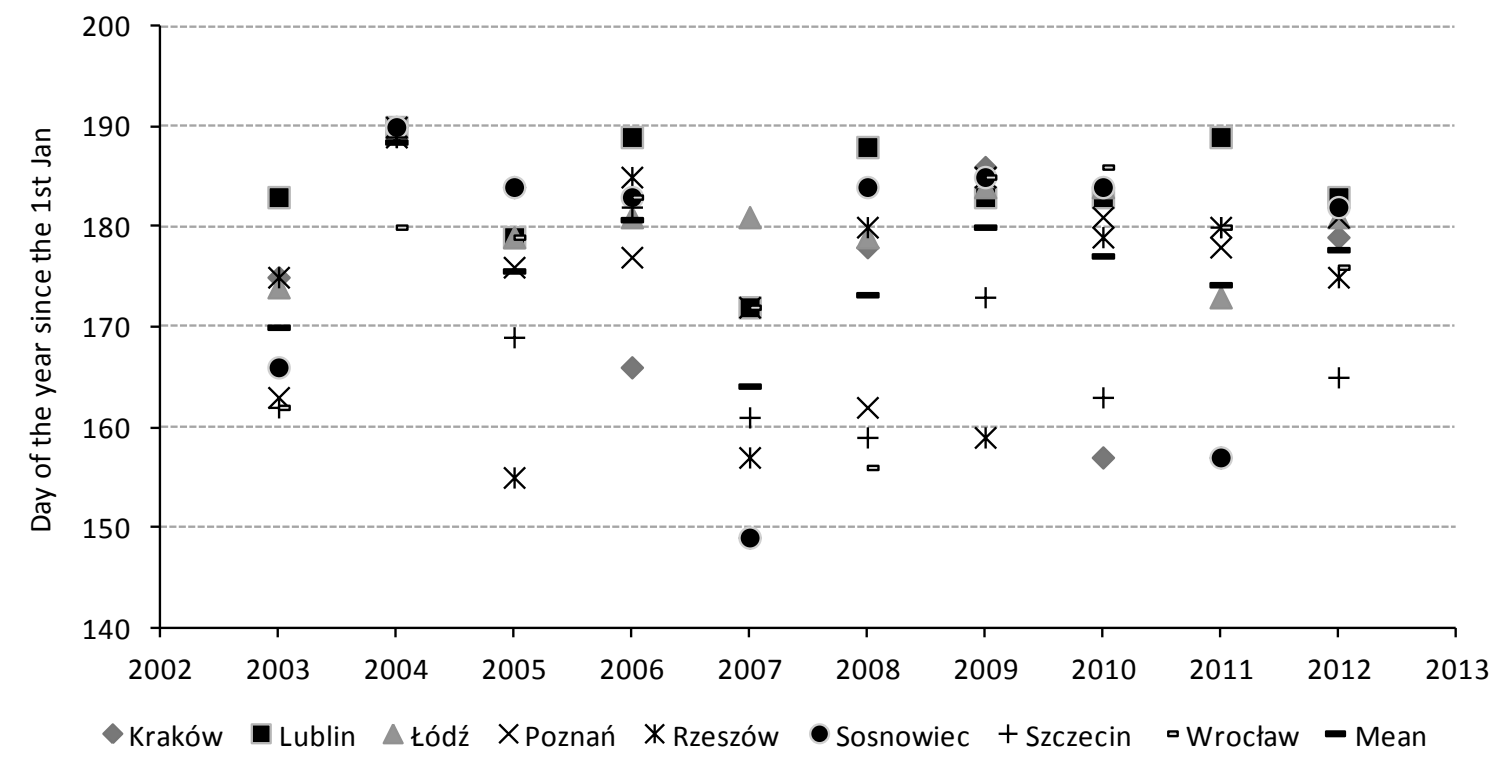

Fig. 6 Dates when the maximum grass pollen concentration was achieved in the studied stations in 2003-2013.

first decade of July; Fig. 6). The days in which the maximum concentration was detected differed between stations in all studied seasons and had no evident relationship with meteorological conditions, apart from 2004. In this year, in most of the stations, the maximum pollen count was observed on the 7th and 8th of July (only in Wrockaw on the 28 th of June). In the indicated days, the weather was shaped by the high pressure system in Poland. It was sunny ( $>8$ sun hours/day) throughout the country, with little cloud cover. Maximum temperature of the air on the 7th July 2004 fluctuated from $18^{\circ} \mathrm{C}$ in Szczecin (one day later $24^{\circ} \mathrm{C}$ ) to $22^{\circ} \mathrm{C}$ in Wrocław (one day later $27^{\circ} \mathrm{C}$ ). The humidity at noon was low (40-50\%), and the wind was weak and blow from different directions. In other years the maximum concentration was detected in days of different weather types, what made the problem to find the clear relationship between this season characteristic and meteorological elements.

\section{Discussion}

Studies on the occurrence and dynamics of pollen seasons often focus on the influence of different meteorological factors on the pollen season characteristics and the pollen concentration [23]. It is crucial information for people sensitive to pollen from view of diagnostics, therapy and prophylaxis of allergic rhinitis [24-27].

\section{Pollen season timing}

In comparison to the other taxa, Poaceae pollen seasons show the stability of the appearance dates [28,29]. It refers especially to the start and end of the pollen season [30,31]. In the current paper, the values of the coefficient of variation ( $V \%$ ) did not achieve $10 \%$ in case of season start and $20 \%$ in case of season end. Grass pollen seasons in Poland are definitely more stable then tree pollen seasons, the most evident seen in case of early-pollinating tress (like alder and hazel), but the tree pollen seasons are more variable at the season start, while in case of grasses, the end of the season vary clearly from year to year [8].

It is known that the timing and magnitude of grass pollen seasons differ between regions due to factors that affect abundance and dispersal $[4,16]$. The differences in season time in Poland are as follows: mean season start differs up to 9 days among the stations, season end differs up to one month, while season duration differs up to 20 days. It was noted on the basis of the study performed in 12 European cities, in 1985-1997, that grass pollen seasons started in the south (Spain) the earliest due to the warmer weather conditions in the spring and early summer, followed by the West regions and finally Northern Europe (Finland), where the latest pollen season were observed [16]. It was concluded that the variability of start dates tends increase with latitude.

On the other hand, Smith et al. [18] reported that latitude is the main factor describing the spatial variation in the timing of the grass pollen seasons at the 13 sites in Europe. This observation is related to the accumulation of temperature from the start of the growing season. This study shown also the influence of the large-scale patterns on the grass pollen seasons, including NAO, through its effect on temperature and precipitation. However, the impact of NAO is well seen in Western Europe, in the locations along the coast only. In our study the impact of longitude on the pollen season timing was rather found and the evident relationship with temperature in the months preceding and during the pollen season was revealed.

Low variability of the grass pollen season start makes this season characteristic of a great predictive value. Myszkowska [31] proposed the factor predictive models arranged using as independent variables: cumulative mean daily temperature, effective cumulative temperature ranging from 5 to $15^{\circ} \mathrm{C}$ and the sum of daily temperature amplitudes $\left[\Sigma\left(T_{\max }-T_{\min }\right)\right]$. The application of factor regression analysis allowed to indicate some phenomena of the plants property: when cumulative 
mean daily temperature increased by $10^{\circ} \mathrm{C}$, the season start was accelerated by 1 day. On the other hand, when the sum of daily temperature amplitudes increased by $10^{\circ} \mathrm{C}$, the season started 3 days earlier.

\section{Pollen season intensity}

It was noted that the highest grass pollen concentrations were observed in summer, in the conditions of high temperature and precipitation. This observation is important not only from botanical, but also from medical point of view. Most of the patients manifest the symptoms of allergic rhinitis provoked by the pollen allergens in summer, the time of the high grass pollen exposure [1,5-7]. The high pollen load is also responsible for the increase of allergic asthma symptoms in patients sensitive to grass pollen. Erbas et al. [32] indicated the pollen concentration of $30 \mathrm{PG} / \mathrm{m}^{3}$ as the threshold value at which the clinical symptoms are observed. The information of the year-to-year fluctuation of seasonal pollen intensity makes the estimation of efficacy of pollen allergy treatment more objective [33].

In the current study the pollen annual sum (presented as SPI value) differed clearly from year to year, what was not stressed in the long-scale research performed in Europe by Spieksma et al. [17]. In Poland the weather conditions in summer are relatively stable. In spite of that the grass pollen severity symptoms varies strongly within seasons [34]. It is worth to underline, that apart from temperature, precipitation in summer influenced the pollen count. The relationship between pollen concentration and precipitation before the pollen season was observed in the Mediterranean regions, confirming that the development of grasses is positively

\section{Acknowledgments}

The study was carried out thanks to the cooperation of the aerobiological stations in Poland in frame of the Polish Aerobiological Network.

\section{Authors' contributions}

The following declarations about authors' contributions to the research have been made: study idea and design: DM, MZ, EWC; acquisition of aerobiological data: $\mathrm{MZ}, \mathrm{KC}, \mathrm{KDZ}$, IK, BMW, MM, MN, KPW, MP, EWC; acquisition of meteorological data analysis and interpretation of data: DM, KP, MZ; drafting of manuscript: DM, KP, MZ, IK, ŁG.

\section{Competing interests}

The following declarations about authors' competing interests have been made: EWC is a honorary editor of the Acta Agrobotanica; other authors: no competing interests.

\section{References}

1. D’Amato D, Cecchi L, Bonini S, Nunes C, Annesi-Maesano I, Behrendt $\mathrm{H}$, et al. Allergenic pollen and pollen allergy in Europe. Allergy. 2007;62(9):976-990. http://dx.doi. org/10.1111/j.1398-9995.2007.01393.x

2. Falkowski M. Trawy polskie. Warszawa: Państwowe Wydawnictwo Rolnicze i Leśne; 1982.

3. Frey L. Taksonomia traw. In: Frey L, editor. Biologia traw. Kraków: Instytut Botaniki im. W. Szafera Polska Akademia Nauk: 2007. p. 39-63.

4. Szczepanek K. Pollen calendar for Cracow (southern Poland), 19821991. Aerobiologia. 1994:10(1):65-70. http://dx.doi.org/10.1007/ BF02066749

5. Samoliński B, Sybilski AJ, Raciborski F, Tomaszewska A, Samel-Kowalik P, Walkiewicz A, et al. Prevalence of rhinitis in Polish population influenced by water availability in spring months [13]. The comparative study carried out in Spain and England indicated that the intensity of the grass pollen season is controlled by two main factors: temperature and precipitation [15]. On the other hand, in Brisbane (Australia) the significant relation between grass pollen concentration during each sampling year (1994-1999) and temperature was reported, while precipitation was considered as less important parameter [35].

\section{Conclusions}

The grass pollen seasons vary among regions according to the season timing and intensity.

The pollen season started in the middle of May on average, pollen season start coincidences with the course of monthly average air temperature in April and May.

Pollen season ends were more changeable in comparison to the season start and fluctuated from the middle of July to the middle of September.

Pollen seasonal concentration clearly depended on temperature and precipitation in April-August, warm and moist conditions effect the high pollen load, the dependence is best seen in July-August. In general, the hot and dry summer, and cold and rainy summer are not the optimal condition for pollen release.

Maximum pollen concentrations, achieved in given days between the end of May and the first decade of July, have not been related to the specific weather conditions common for all studied stations.

according to the ECAP (Epidemiology of Allergic Disorders in Poland) study. Otolaryngol Pol. 2009;63(4):324-330. http://dx.doi.org/10.1016/ S0030-6657(09)70135-0

6. Obtułowicz K, Szczepanek K, Szczeklik A. The value of pollen count for diagnosis and therapy of pollen allergy in Poland. Grana. 1990:29;318-320. http://dx.doi.org/10.1080/00173139009428943

7. Obtułowicz K, Szczepanek K, Radwan J, Grzywacz M, Adamus $\mathrm{K}$, Szczeklik A. Correlation between airborne pollen incidence, skin prick tests and serum immunoglobulin in allergic people in Cracow, Poland. Grana. 1991;30:136-141. http://dx.doi. org/10.1080/00173139109427787

8. Weryszko-Chmielewska E. Ziarna pyłku i zarodniki grzybów w powietrzu różnych regionów Polski. Warszawa: Norbertinum; 2014.

9. Gehrig R. The influence of the hot and dry summer 2003 on the pollen season in Switzerland. Aerobiologia. 2006;22:27-34. http:// dx.doi.org/10.1007/s10453-005-9013-8

10. Piotrowicz K, Myszkowska D. Charakterystyka sezonów pyłkowych wybranych taksonów roślin w Krakowie na tle warunków meteorologicznych. In: Kłysik K, Wibig J, Fortuniak K, editors. Klimat i bioklimat miast. Łódź: Wydawnictwo Uniwersytetu Łódzkiego: 2008. p. 301-311.

11. Piotrowska K. The effect of meteorological factors on the start of grass pollen season in Lublin in the years 2001-2004. Acta Agrobot. 2006;59:365-372. http://dx.doi.org/10.5586/aa.2006.038

12. Spieksma FTM, Nikkels H. Airborne grass pollen in Leiden, the Netherlands: annual variations and trends in quantities and season starts over 26 years. Aerobiologia. 1998;14:347-358. http://dx.doi. org/10.1007/BF02694304

13. Garcia-Mozo H, Galán C, Alcázar P, Diáz de la Guardia C, NietoLugilde D, Recio M, et al. Trends in grass pollen season in southern 
Span. Aerobiologia. 2010;26:157-169. http://dx.doi.org/10.1007/ s10453-009-9153-3

14. Emberlin J, Mullins J, Corden J, Jones S, Millington W, Brooke M, et al. Regional variations in grass pollen seasons in the UK, long term trends and forecast models. Clin Exp Allergy. 1998;29:347-356. http:// dx.doi.org/10.1046/j.1365-2222.1999.00369.x

15. Sánchez Mesa JA, Smith M, Emberlin J, Allitt U, Caulton E, Galan C. Characteristics of grass pollen seasons in areas of southern Spain and the United Kingdom. Aerobiologia. 2003;19:243-250. http://dx.doi. org/10.1023/B:AERO.0000006597.44452.a3

16. Emberlin J, Jaeger S, Dominguez-Vilches E, Galan Soldevilla C, Hodal $\mathrm{L}$, Mandrioli $\mathrm{P}$, et al. Temporal and geographical variations in grass pollen seasons in areas of Western Europe: an analysis of season dates at sites of the European pollen information system. Aerobiologia. 2000;16:373-379. http://dx.doi.org/10.1023/A:1026521331503

17. Spieksma FTM, Corden JM, Detandt M, Millington WM, Nikkels $\mathrm{H}$, Nolard $\mathrm{N}$, et al. Quantitive trends in annual totals of five common airborne pollen types (Betula, Quercus, Poaceae, Urtica, and Artemisia), at five pollen-monitoring stations in western Europe. Aerobiologia. 2003;19:171-184. http://dx.doi. org/10.1023/B:AERO.0000006528.37447.15

18. Smith M, Emberlin J, Stach A, Rantio-Lehtimäki A, Caulton E, Thibaudon M, et al. Influence of the North Atlantic Oscillation on grass pollen counts in Europe. Aerobiologia. 2009;25:321-332. http:// dx.doi.org/10.1007/s10453-009-9136-4

19. Stach A, Kasprzyk I. Metodyka badań zawartości pyłku roślin i zarodników grzybów w powietrzu z zastosowaniem aparatu Hirsta. Poznań: Bogucki Wydawnictwo Naukowe; 2005.

20. Moore PD, Webb JA, Collinson ME. Pollen analysis. Oxford: Blackwell Science; 1991.

21. Galán C, Smith M, Thibaudon M, Frenguelli G, Clot B, Gehrig R. Pollen monitoring: minimum requirements and reproducibility of analysis. Aerobiologia. 2014;30:385-395. http://dx.doi.org/10.1007/ s10453-014-9335-5

22. Jato V, Rodríguez-Rajo FJ, Alcázar P, de Nuntiis P, Galán C, Mandrioli P. May the definition of pollen season influence aerobiological results? Aerobiologia. 2006;22:13-25. http://dx.doi.org/10.1007/ s10453-005-9011-x

23. Weryszko-Chmielewska E. Zakres badań i znaczenie aerobiologii. In: Weryszko-Chmielewska E, editor. Aerobiologia. Lublin: Wydawnictwo Akademii Rolniczej; 2007. p. 6-10.

24. Obtułowicz K, Myszkowska D. Alergia pyłkowa. Kraków: Wytwórnia Surowic i Szczepionek BIOMED w Krakowie; 1995.

25. Rapiejko P. Znaczenie pomiaru stężeń pyłku roślin dla oceny skuteczności pyłkowicy. Alergia Astma Immunologia. 2000;5(2):40-42.

26. Frenz DA. Interpreting atmospheric pollen counts for use in clinical allergy: allergic symptomology. Ann Allergy Asthma Immunol. 2001;86:150-158. http://dx.doi.org/10.1016/S1081-1206(10)62683-X

27. Myszkowska D. Zastosowanie badań aerobiologicznych w medycynie.
In: Weryszko-Chmielewska E, editor. Aerobiologia. Lublin: Wydawnictwo Akademii Rolniczej; 2007. p. 85-89.

28. Kasprzyk I, Walanus A. Description of the main Poaceae pollen season using Bi-Gaussian curves, and forecasting methods for the start and peak dates for this type of season in Rzeszów and Ostrowiec Św. (SE Poland). J Environ Monit. 2010;12:906-916. http://dx.doi. org/10.1039/b912256g

29. Kasprzyk I. Time series analysis of pollen seasons in Rzeszów (SE Poland) in 1997-2005 with reference to phenology [Habilitation thesis]. Rzeszów: Wydawnictwo Uniwersytetu Rzeszowskiego; 2011.

30. Myszkowska D. The grass pollen season dynamics in relation to the meteorological conditions in Cracow, southern Poland, 1991-2008. Acta Agrobot. 2010;63:85-96. http://dx.doi.org/10.5586/aa.2010.036

31. Myszkowska D. Poaceae pollen in the air depending on the thermal conditions. Int J Biometeorol. 2014;58,975-986. http://dx.doi. org/10.1007/s00484-013-0682-7

32. Erbas B, Chang JH, Dharmage S, Ong EK, Hyndman R, Newbigin $\mathrm{E}$, et al. Do levels of airborne grass pollen influence asthma hospital admissions? Clin Exp Allergy. 2007;37:1641-1647. http://dx.doi. org/10.1111/j.1365-2222.2007.02818.x

33. Obtułowicz K, Myszkowska D, Steppalska D. The efficacy of symptomatic treatment of pollen allergy with regard to pollen concentration - introduction of a new coefficient. J Allergy Clin Immunol. 2000;12(3):105-109.

34. Kożuchowski K. Klimat Polski. Nowe spojrzenie. Warszawa: Państwowe Wydawnictwo Naukowe PWN; 2011.

35. Green BR, Dettmann M, Yli-Panula E, Rutheford S, Simpson R. Atmospheric Poaceae pollen frequencies and associations with meteorological parameters in Brisbane, Australia: a 5-year record, 1994-1999. Aerobiologia. 2004;48:172-178. http://dx.doi.org/10.1007/ s00484-004-0204-8

\section{Sezony pyłkowe traw w Polsce na tle warunków meteorologicznych}

\section{Streszczenie}

Artykuł dotyczy oceny sezonów pyłkowych Poaceae w Polsce w wybranych regionach. Celem pracy było przedstawienie wieloletniej zmienności początku, końca i długości sezonów pyłkowych traw oraz sezonowego indeksu pyłkowego (wartość SPI) w Polsce na tle warunków meteorologicznych. Badania były prowadzone w ośmiu miastach Polski, w okresie 1992-2014 (sezony 2003-2012 były wspólne dla wszystkich miast). Początek sezonu pyłkowego był względnie stały w okresie badawczym, sezony rozpoczynały się około 10 maja, nieco wcześniej w południowej części Polski. Koniec sezonu pyłkowego był bardziej zmienny w porównaniu do początku, jego termin wahał się od połowy lipca do połowy września. SPI wyraźnie zależał od temperatury i opadów w okresie kwiecień-sierpień. Dobowe stężenie maksymalne pyłku były odnotowywane pomiędzy końcem maja a pierwszą dekadą lipca, nie wykazano wyraźnej zależności pomiędzy dniem stężenia maksymalnego i warunkami pogodowymi, z wyjątkiem 2004 roku. 